\title{
First description of a Bald Eagle (Haliaeetus leucocephalus) actively depredating an adult Sandhill Crane (Antigone canadensis)
}

\author{
Andrew J. Caven ${ }^{1, *}$, Joshua D. Wiese ${ }^{1}$, William R. Wallauer ${ }^{2}$, and Kristin J. Mosher ${ }^{2}$ \\ ${ }^{1}$ Platte River Whooping Crane Maintenance Trust, Wood River, NE 68883 \\ ${ }^{2}$ The Jane Goodall Institute, Vienna, VA 22182
}

\begin{abstract}
From late February to early April the Central Platte River Valley in Nebraska is home to the largest gathering of Sandhill Cranes (Antigone canadensis) in the world and increasingly serves as a foraging ground for migrating Bald Eagles (Haliaeetus leucocephalus). On 7 March 2017, we documented a subadult Bald Eagle depredating an adult Sandhill Crane. Though evidence suggests that Bald Eagles depredate Sandhill Cranes on rare occasion, the process of that depredation has not been described in the scientific literature. The Sandhill Crane effectively defended itself several times against hovering attacks from the Bald Eagle by utilizing wing-spread displays and "bill stab" attacks. However, the Bald Eagle was eventually able to land on the Sandhill Crane's neck and back with its talons, push the crane's head under water, and drown its prey. Following submersion, the Sandhill Crane was only momentarily responsive before floating on its back down the river. We also documented 5 subadult Bald Eagles competing for access to a second Sandhill Crane carcass. As Bald Eagle populations continue to recover, Sandhill Cranes may become more frequently depredated by Bald Eagles during the spring migration-staging period in the Central Platte River Valley.
\end{abstract}

Resumen.-Desde finales de febrero a principios de abril, el valle del río Central Platte en Nebraska es hogar de la concentración más grande a nivel mundial de grullas canadienses (Antigone canadensis), y sirviendo cada vez más como área de forrajeo para las águilas calvas migratorias (Haliaeetus leucocephalus). El 7 de marzo del 2017, registramos un sub-adulto de águila calva depredando a una grulla canadiense adulta. Aunque, las evidencias indican que únicamente en raras ocasiones las águilas calvas depredan a las grullas canadienses, el proceso de esta depredación aún no ha sido descrita en la literatura científica. La grulla canadiense se defendió reiteradas ocasiones contra los ataques del águila calva desplegando sus alas y picoteando. Sin embargo, el águila calva, logro alcanzar con sus garras el cuello y el lomo de la grulla canadiense y hundir su cabeza en el agua, ahogando a su presa. La grulla canadiense reaccionó momentáneamente, después de la inmersión, antes de flotar boca abajo en el río. También, registramos cinco sub-adultos de águila calva compitiendo por acceder a otra grulla canadiense muerta. Las grullas canadienses podrían convertirse en presas más comunes del águila calva, durante su período migratorio de primavera en el valle del río Central Platte, a medida que la población del águila calva continúe recuperándose.

The Central Platte River Valley (CPRV) in south central Nebraska is home to the largest, most concentrated Sandhill Crane (Antigone canadensis L.; SACR) roosting area in North America, with annual peak numbers exceeding 500,000 across a $132-\mathrm{km}$ reach of river in late March (Krapu et al. 2014). The CPRV also serves as habitat for wintering, migrating, and breeding Bald Eagles (Haliaeetus leucocephalus L.; BAEA), which peak in abundance during their spring migration in late February and March (Sharpe et al. 2001). The Platte River is a shallow braided system that provides secure night roosting habitat for migrating SACRs and Whooping Cranes (Grus americana L.) on shallow submerged sandbars (Krapu et al. 2014). The surrounding landscape is composed of irrigated crop fields, lowland prairies, and riparian woodlands which have expanded into river channels over the past century with the appropriation of flows for agricultural use (Currier 1982, Krapu et al. 2014). Consequently, the CPRV contains a much larger expanse of mature eastern cottonwood forest (Populus deltoides W. Bartram ex Marshall) than it did a century ago (Currier 1982), and that forest provides perching and nesting habitat for the BAEAs that increasingly utilize the area (Anthony and Isaacs 1989, Buehler et al. 1992, Sharpe et al. 2001).

*Corresponding author: acaven@cranetrust.org 


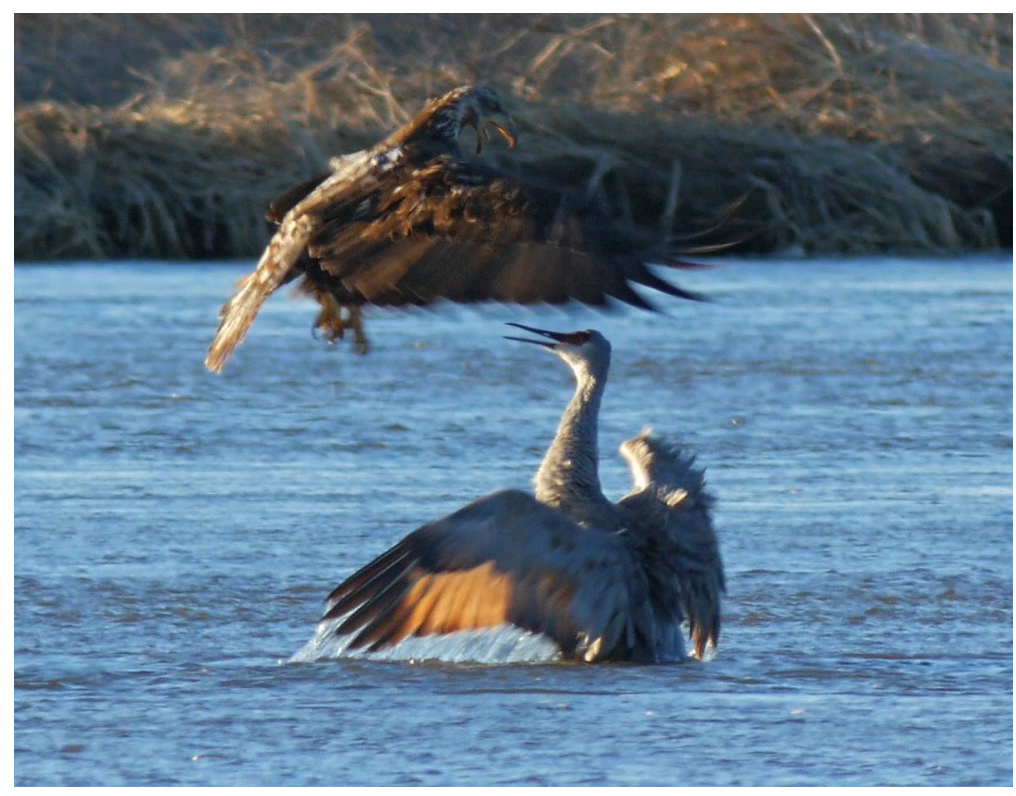

Fig. 1. Third-year Bald Eagle (Haliaeetus leucocephalus) hovering over an adult Sandhill Crane (Antigone canadensis) completing a defensive wing-spread display on 7 March 2017 in the main channel of the Platte River, Hall County, Nebraska, USA. Photo by W. Wallauer.

On 7 March 2017, we witnessed a BAEA attacking and potentially killing a SACR, as well as a group of 5 subadult BAEAs foraging on an additional SACR carcass. We observed the events from a viewing blind on the north bank of the main channel of the Platte River $\left(40^{\circ} 45^{\prime} 40^{\prime \prime} \mathrm{N}, 98^{\circ} 31^{\prime} 22^{\prime \prime} \mathrm{W}\right.$, WGS 84; $600 \mathrm{~m}$ elevation) from a distance of about $350 \mathrm{~m}$. We recorded the events with a Panasonic Lumix GH-4 camera equipped with a $400-\mathrm{mm}$ lens and $2 \times$ extender (approximately $53 \times$ zoom). The viewing blind was located on the edge of a 617-ha property managed for the benefit of threatened and endangered species. At this location, the river channel was approximately $400 \mathrm{~m}$ wide. This river reach often supports one of the highest densities of roosting SACRs in the CPRV (Krapu et al. 2014). Weekly aerial surveys estimated at least 80,000 SACRs roosting within $1600 \mathrm{~m}$ of the viewing blind on the evening of 8 March 2017 (Crane Trust unpublished data).

At approximately 7:20 AM Central Standard Time (sunrise: 6:58 AM), several thousand SACRs flushed from their roost, and we detected a subadult BAEA hovering $1 \mathrm{~m}$ above an adult SACR. The BAEA attempted a strike with its talons but made minimal contact with the tip of the SACR's right wing before landing up to its sternum in about 25 $\mathrm{cm}$ of water. The SACR completed a "wingspread display," with its wings open and angled downward and its neck extended upward facing its attacker (Ellis et al. 1996; Fig. 1). This is one of the most agonistic SACR behaviors and is often employed while a crane is approaching or backing away from a predator (Ellis et al. 1996). The SACR's right wing appeared to not open fully, suggesting possible injury. We estimated the BAEA's age to be 3.5 years (hereafter, 3.5-year BAEA) by its plumage pattern (McCollough 1989). The SACR did not attempt to fly away following the initial attack, and it drank and foraged from the river within $3 \mathrm{~m}$ of the loafing BAEA. Facing away from the SACR, the BAEA vocalized, possibly as a display of dominance to the other BAEAs in the area (Hansen 1986). The 3.5-year BAEA was periodically joined by a 1.5-year BAEA on the sandbar, but the younger bird made no attempt to assist in the depredation. The SACR returned a vocalization in the direction of the BAEA, but our observation distance made describing the call type impossible. Both "alarm" and "guard" calls are associated with wing-spread displays in SACRs and are given in response to predatory threats (Ellis et al. 1996). The 3.5-year 


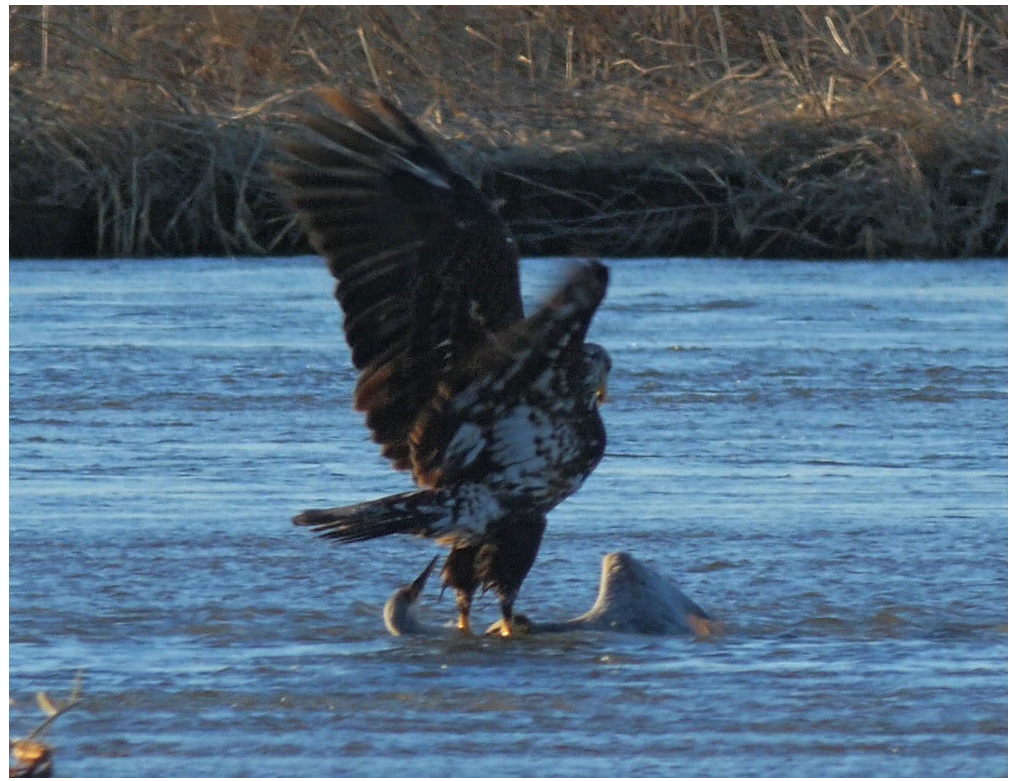

Fig. 2. Third-year Bald Eagle (Haliaeetus leucocephalus) with talons around the neck and dug into the back of an adult Sandhill Crane (Antigone canadensis) as it repeatedly pushed the crane's head underwater over a period of $21 \mathrm{~s}$ on 7 March 2017 in the main channel of the Platte River, Hall County, Nebraska, USA. Photo by W. Wallauer.

BAEA made 3 additional unsuccessful attempts to attack the SACR by taking flight, hovering over it, and grasping at its head or neck with its talons. The SACR continued to complete wing-spread displays in conjunction with "bill stab" defenses, which include thrusting an open or closed bill at potential predators (Ellis et al. 1996). The SACR backed away from the BAEA during depredation attempts and eventually entered into deeper water (approximately $40-45 \mathrm{~cm}$ ). The BAEA rested on a shallow sandbar approximately $20 \mathrm{~cm}$ deep before again taking flight and hovering over the SACR, which horizontally extended its neck and body to give an aggressive but inaccurate bill stab toward the BAEA. The BAEA then dropped one talon onto the center of the SACR's back and another around the base of its outstretched neck, forcing the SACR's head underwater intermittently for a period of $21 \mathrm{~s}$ (Fig. 2). The BAEA then lifted off of the SACR and returned to a nearby sandbar. The SACR made an attempt to stand and the BAEA lifted back into the air over it. The SACR attempted a bill stab and fell onto its back with its wings extended and remained motionless as it drifted down river. The depredation attempt lasted just under 6 min and its success was uncertain. The drifting
SACR was not pursued by the BAEA, which flew to join 4 other BAEAs competing over an additional SACR carcass.

It is unclear if one of the 5 BAEAs documented herein caused the death of the additional SACR. We aged all 5 BAEAs by utilizing the plumage molting sequence described by McCollough (1989) and determined that 1 was 1.5 years old, 2 were 2.5 years old, and 2 were 3.5 years old. We estimated the amount of time that each age class had access to the carcass by utilizing $39 \mathrm{~min}$ and $12 \mathrm{~s}$ of video footage. On average, the 3.5-year BAEAs tended the carcass the longest (average $=$ 16:03 $\mathrm{min}$ ), followed by the 2.5-year BAEAs (average $=9: 56 \mathrm{~min}$ ), as would be expected from the scientific literature (Hansen 1986). The 1.5-year BAEA only gained control of the carcass during 2 brief occasions (totaling 2:44 min) when older BAEAs were engaged in tail chases while defending the SACR remains. BAEAs learn important aspects of foraging socially by following older conspecifics. They also have flexible diets and can adapt to novel food items when resources are limited (Knight and Knight 1983, Stalmaster and Plettner 1992). It is possible that BAEA populations could learn to utilize SACRs as prey locally if they do not commonly do so 
already (Knight and Knight 1983, Lefebvre and Bouchard 2003).

BAEA populations have continued to increase throughout the United States following conservation efforts beginning in the 1970 s, and this resurgence has been pronounced in the CPRV, bringing an increasing number of BAEAs in contact with spring staging SACRs (Lingle and Krapu 1986, Sharpe et al. 2001). Contact between SACRs and BAEAs is likely promoted by a significant increase in mature cottonwood forest in the CPRV (Currier 1982, Anthony and Isaacs 1989, Buehler et al. 1992). Wintering and migrating BAEAs prefer a diet of fish, but are known to hunt geese, ducks, and coots near the CPRV (Stalmaster and Plettner 1992). SACR remains have been found in BAEA pellets in the CPRV (Lingle and Krapu 1986) and in 2 BAEA nests in Florida (Wood et al. 1993). This evidence suggests occasional depredation. However, because BAEAs are known to feed on carrion and to kleptoparasitize other raptor species, the evidence is not definitive (Jorde and Lingle 1988, Stalmaster and Plettner 1992).

Lewis (1974) suggested that the flushing behavior of SACRs in response to BAEAs indicates that SACRs may occasionally be prey of BAEAs. Walkinshaw (1949) mentioned that BAEAs reportedly attack SACRs in Nebraska but presented no description of such events. However, Walkinshaw (1949) contended that SACRs are rarely depredated unless they are young, sick, or injured. Nesbitt and Archibald (1981) documented a SACR effectively defending itself against a juvenile BAEA by utilizing bill stab displays in combination with forward thrusts of the body, feet, and wings. Ellis et al. (1999) documented 4 successful depredations of adult Greater Sandhill Cranes (Antigone canadensis tabida Peters 1925) and one unsuccessful attempt on a Whooping Crane by Golden Eagles (Aquila chrysaetos L.) during experimental aircraftled migration flights associated with Whooping Crane reintroduction. However, these experimental flights were significantly lower in altitude than wild crane migrations, potentially exposing the birds to a higher risk of depredation (Ellis et al. 1999). Olsen and Gee (1997) documented Great Horned Owls (Bubo virginianus Gmelin 1788) depredating 2 captive adult SACRs, and Genter (1985) documented a Northern Harrier (Circus hudsonius L.) killing a 5-week-old SACR in Montana. There is, however, little record of any avian predator successfully depredating a wild, healthy adult SACR (Tacha et al. 1992).

As Lima (1993) notes, there are no known antipredator escape behaviors documented in the world's crane species, potentially because of their size. Tacha et al. (1992) reports that SACRs generally respond to avian predators by vaulting into the air and kicking their feet forward. It is possible that an injured right wing or some other physical limitation reduced this SACR's defensive abilities. To our knowledge, the only other record of a BAEA utilizing drowning as a depredation technique on avian prey involves a Great Blue Heron (Ardea herodias L.) (D’Auria 2013). It is possible that drowning is a method BAEAs employ to effectively depredate wading birds. Given the previous records of SACR remains in BAEA pellets in the CPRV, it is possible that BAEAs depredate SACRs with some regularity during February and March when their migrations overlap. As eagle populations continue to recover and expand, SACRs may become more common prey of BAEAs migrating through the CPRV.

\section{ACKNOWLEDGMENTS}

This manuscript is dedicated to the late Jerry Kenny and his partner Bridget Baron, who kindly provided us access to the Platte River Recover and Implementation Program's Henson viewing blind to conduct this research. Conservationists in the Central Platte River Valley and well beyond will greatly miss Jerry's wide-ranging curiosity and dedication to science and endangered species. We also want to thank the Crane Trust for funding the writing of this natural history note and the Jane Goodall Institute for support of this project and its tireless conservation efforts to protect biodiversity around the world.

\section{Literature Cited}

Anthony, R.G., AND F.B. Isaacs. 1989. Characteristics of Bald Eagle nest sites in Oregon. Journal of Wildlife Management 53:148-159.

Buehler, D.A., S.K. Chandler, T.J. Mersmann, J.D. Fraser, and J.K. SeEgar. 1992. Nonbreeding Bald Eagle perch habitat on the northern Chesapeake Bay. Wilson Bulletin 104:540-545.

Currier, P.J. 1982. The floodplain vegetation of the Platte River: phytosociology, forest development, and 
seedling establishment. Doctoral dissertation, Iowa State University, Ames, IA.

D'Auria, D.E. 2013. Heron observation network of Maine: five year report and future plans. Maine Department of Inland Fisheries and Wildlife, Bangor, ME. https://maineheron.files.wordpress.com/ 2010/03/heron-5yrreport.pdf

Ellis, D.H., K.R. ClegG, L.C. LeWIS, and E. Spaulding, 1999. Golden Eagle predation on experimental Sandhill and Whooping Cranes. Condor 101: 664-666.

ElLis, D.H., G.F. GeE, and C.M. Mirande. 1996. Cranes: their biology, husbandry and conservation. U.S. Department of the Interior, National Biological Service, Washington, DC, and International Crane Foundation, Baraboo, WI.

Genter, D.L. 1985. Northern Harrier kills Sandhill Crane. Wilson Bulletin 97:108-109.

Hansen, A.J. 1986. Fighting behavior in Bald Eagles: a test of game theory. Ecology 67:787-797.

Jorde, D.G., AND G.R. LingLE. 1988. Kleptoparasitism by Bald Eagles wintering in south-central Nebraska. Journal of Field Ornithology 59:183-188.

KNight, S.K., AND R.L. KNight. 1983. Aspects of food finding by wintering Bald Eagles. Auk 100:447-484.

Krapu, G.L., D.A. Brandt, P.J. Kinzel, and A.T. Pearse. 2014. Spring migration ecology of the mid-continent Sandhill Crane population with an emphasis on use of the Central Platte River Valley, Nebraska. Wildlife Monographs 189:1-41.

Lefebvre, L., AND J. Bouchard. 2003. Social learning about food in birds. Pages 94-126 in D. Fragaszy and S. Perry, editors, The biology of traditions: models and evidence. Cambridge University Press, Cambridge, United Kingdom.

LEwIS, J.C. 1974. Ecology of the Sandhill Crane in the southeastern Central Flyway. Doctoral dissertation, Oklahoma State University, Stillwater, OK
LimA, S. 1993. Ecological and evolutionary perspectives on escape from predatory attack: a survey of North American birds. Wilson Bulletin 105:1-47

Lingle, G.R., AND G.L. KRAPU. 1986. Winter ecology of Bald Eagles in south-central Nebraska. Prairie Naturalist 18:65-78.

MCCollough, M.A. 1989. Molting sequence and aging of Bald Eagles. Wilson Bulletin 101:1-10.

Nesbitt, S.A., AND G.W. ARChibaLd. 1981. The agonistic repertoire of Sandhill Cranes. Wilson Bulletin 93: 99-103.

Olsen, G.H, and G.F. Gee. 1997. Causes of Mississippi Sandhill Crane mortality in captivity, 1984-95. Proceedings of the North American Crane Workshop $7: 10-13$.

Sharpe, R.S., W.R. Silcock, and J.G. Jorgensen. 2001. Birds of Nebraska: their distribution and temporal occurrence. University of Nebraska Press, Lincoln, NE.

Stalmaster, M.V., and R.G. Plettner. 1992. Diets and foraging effectiveness of Bald Eagles during extreme winter weather in Nebraska. Journal of Wildlife Management 56:355-367.

Tacha, T.C., S.A. NesbitT, and P.A. Vohs. 1992. Sandhill Crane (Grus canadensis). No. 31 in A. Poole and F. Gill, editors, The birds of North America. The Birds of North America, Inc., Philadelphia, PA.

Walkinshaw, L.H. 1949. The Sandhill Cranes. Bulletin no. 29, Cranbrook Institute of Science, Bloomfield Hills, MI.

Wood, P.B., S.A. Nesbitt, and A. Steffer. 1993. Bald Eagles prey on Sandhill Cranes in Florida. Journal of Raptor Research 27:164-165.

Received 3 April 2018

Revised 8 May 2018

Accepted 11 May 2018

Published online 12 July 2018 